\title{
GROUNDWATER QUALITY INVESTIGATION IN UDAYARPALAYAM TALUK, ARIYALUR DISTRICT, TAMILNADU, INDIA
}

\author{
K. G. Sekar ${ }^{*}$, K. Suriyakala \\ Department of Chemistry, National College, Tiruchirappalli-620001 \\ E-mail address: drkgsekar@yahoo.co.in
}

\begin{abstract}
Keywords: Groundwater, Potability, UdayarpalyamTaluk, AriyalurDistrict, Physicochemical Parameters, Tamilnadu.
\end{abstract}

\begin{abstract}
Ariyalur is one of the districts in Tamilnadu it is rich in limestone resource. A study on geochemical characterization of ground water and its suitability for drinking purposes was carried out. Twenty five groundwater samples were collected from bore wells and open wells during Pre monsoon seasons of 2014. Groundwater is the main principle source for drinking, irrigation water and other activities in our study area. It is an indispensable source of our life. The problem of groundwater quality obtains high importance in this present-day, whether in the study area or any other countries in the world. The present study was carried out to analyse and evaluate the groundwater samples collected from residential areas of Udayarpalyam Taluk. The analyzed physicochemical parameters such as $\mathrm{pH}$, electrical conductivity, total dissolved solids, calcium, magnesium, sodium, potassium, bicarbonate, sulphate, phosphates, chloride, nitrate, and fluoride are used to characterize the groundwater quality and its suitability for drinking uses. Calcium, sodium, chloride and sulphate are the dominant ions in the groundwater chemistry. The Groundwater is not suitable for drinking purposes at several locations in this area. Each parameter was compared with its standard permissible limit as prescribed by WHO/BIS. The analytical results indicated that the ground water quality was found unsatisfactory for drinking purpose in some location.
\end{abstract}

\section{INTRODUCTION}

Water is a prime natural resource, a basic human need and a precious national asset and one of the most stable compounds as well as universal solvent. Besides drinking purpose, it is required for other human activities like cooking, bathing, washing, agriculture, industry, recreation, navigation, fisheries etc. In India, most of the population (85\%) resides in rural areas and they depend mostly on groundwater resources for their daily needs. In which, approximately 50-80\% of the irrigated land is under groundwater consumption. Rapid growth of population, expansion of irrigation and Increasing trend of industrialization has contributed towards rising demand for groundwater in many areas.

The quality of groundwater depends on various chemical constituents and their concentration is mostly derived from the geological data of the particular region. Generally, the quality of groundwater depends on the composition of recharge water, the interaction between the water and the soil, the soil-gas interaction, the rock with which it comes into contact in the unsaturated zone, the residence time, and reactions that take place within the aquifer (Patil, et,al.,)

Groundwater quality in a region is largely determined by both natural processes (dissolution and precipitation of minerals, groundwater velocity, quality of recharge water, and interaction with other types of water aquifer) and anthropogenic activities. The natural chemical quality of groundwater is generally good, but elevated concentrations of a number of constituents can cause problems for water use (Sajil Kumar and James, 2013). The surface as well as groundwater quality induces environmental degradation over long period of time because of discharge of highly contaminated effluent accelerated by over exploitation of existing water resources. During infiltration, recharged water interacts with soils, weathered materials, and fractured rocks and 
carries pollutants released from the land use activities; these pollutants are dissolved depending upon their solubility in the water, before reaching the groundwater body.

The deterioration of groundwater quality affects its usage for drinking, agriculture, and industrial activities. In developing countries like India, around $80 \%$ of all diseases are directly related to poor drinking water quality and polluted conditions. The principles governing the chemical characteristics of groundwater were well documented in many parts of the world (Navneen Kumar and Sinha, 2010). In order to understand the pollution trends and impacts on aquifers, it is essential to have knowledge of the natural baseline quality so that imposed environmental change can be measured with an acceptable degree of confidence. The geochemistry of groundwater data gives crucial evidence to the geologic history of rocks and indications of groundwater recharge, movement, and storage (Nandababu Singh Laishram, 2013). Water needed for irrigation of cultivated land is being degraded in terms of quantity and quality due to growing demand for the use of water. Moreover, the crop productivity is associated with the quality of soil and the quality of the water available for irrigation. Irrigation is necessary for agricultural production in infertile and semiarid regions where rainfall is not sufficient to uphold crop growth (Nagarajan, et,al.,). Irrigated agriculture consumes $60-80 \%$ of the total water usage and contributes nearly $38 \%$ of the global food production.

It has played a major role in generating employment opportunities in the rural areas and providing food for low prices for downtrodden people in the urban area. There is no documented evidence of the chemical quality of the suitability of groundwater for irrigation purpose in this basin. To investigate the effects of the industrial activities and increase of human population on groundwater quality in the region since groundwater resources are widely used for drinking, agricultural and industrial purposes. The specific objectives of the study are (i) The preliminary investigation and interpretation of the groundwater quality of Udayarpalyam area and (ii) Finding the suitability of groundwater for drinking and irrigation purposes.

\section{MATERIALS AND METHODS}

\subsection{Study area:}

The chosen area of study, the Ariyalur District, Udayarpalyam taluk is spread an area 943.30 sq.km. The area is located between the East longitudes $78^{\circ} 40^{\prime}$ and $10^{\circ} 30^{\prime} \mathrm{E}$ and North latitudes $10^{\circ} 54^{\prime}$ and $11^{\circ} 30^{\prime} \mathrm{N}$, it is almost a coastal district of the Survey of Indian toposheet No$58 \mathrm{M} / 7$ and $58 \mathrm{M} / 8$. A major part of the study region is completely covered by red soil. A major part of the study area falls in socially and economically backward area. In few places alluvial soil and sandy soil. The major crops growth in the study area are Paddy, Millet, Pulses Oilseed ,Sugar cane, Black gram ,Sunflower ,Cotton, Raise, Ground nut, Cashew nut, Vegetables and some other common crops .Agriculture, the major occupation of the people of the study area. The ground water source is through bore well and open well. Ground water is generally using for drinking and irrigation purpose in this study area.

\subsection{Methodology: Sample collection and analysis}

Groundwater samples were collected during the year 2014 in pre -monsoon (July) from twenty five bore wells which are almost uniformly distributed over the study area. The depth of the bore wells varies from 190 to340 ft. Samples were collected in one litre capacity high density polyethylene (HDPE) bottles. Prior to collection, the bottles were thoroughly washed with dilute Nitric acid, and then with distilled water in the laboratory before sample filling. Each bottle was rinsed to avoid any possible contamination in bottling and every other precautionary measure was taken. Groundwater samples were analyzed in the laboratory for major cations and anions. $\mathrm{pH}$ and electrical conductivity (EC) were measured within a few hours by using Elico $\mathrm{pH}$ and conductivity meter, respectively. The total hardness $(\mathrm{TH})$ and calcium were estimated by titrimetric method using EDTA and magnesium concentration was estimated by the difference in the hardness and calcium, and chloride was determined by the Argent metric titration method. Bicarbonate was estimated with hydrochloric acid, and sulphate was determined by precipitating Barium sulphate 
using. The concentrations of sodium and potassium were estimated by flame photometer, and nitrate ions were analyzed by the UV-Visible Spectrophotometer.

\section{RESULTS AND DISCUSSION}

The descriptive statistics of the physicochemical parameters of the analytical data and the permissible limits of various organizations such as World Health Organization (WHO), Indian Standard Institution (ISI), and Bureau of Indian Standards (BIS) are presented in Table3.The statistical parameters of the variable like minimum, maximum and average of different geochemical parameters of ground water is summarized in table 5 .

\subsection{Hydrogen ion concentration $(\mathrm{pH})$ :}

$\mathrm{pH}$ is a measure of the balance between the concentration of hydrogen ions and hydroxyl ions in water. The $\mathrm{pH}$ of an aqueous solution is controlled by interrelated chemical reactions that procedure or consume hydrogen ions. The desirable $\mathrm{pH}$ range for drinking water is 6.5 to 8.5 . The water samples had $\mathrm{pH}$ in the pre-monsoon water samples varies from 7.12 to 8.52 with an average around 7.82 with indicating near to alkaline nature (Fig.2). The entire collected sample had lying with in BIS permissible limit, showing that all the samples were almost neutral and harmless. (Table-5)

\subsection{Temperature:}

The temperature of the water is important for its effect on the chemical and biological reactions of the organisms in water. Temperature is an essential factor in the determination of other parameters like conductivity $\mathrm{pH}$, etc., the temperature of the samples ranged from $26.1^{\circ} \mathrm{C}$ to $32.6^{0} \mathrm{C}$ (Table-1) with an average $29.2^{0} \mathrm{C}$ (Fig.2).

\subsection{Turbidity:}

Turbidity in natural water is caused by clay, organic matter, phytoplankton etc., and the turbidity of ground water sample from Udayarpalyam region range from 2.54 NTU to 0.11 NTU(Fig.2) with an average value1.19 (Table-5).

\subsection{Electrical Conductivity:}

Electrical conductivity is the capacity of water to convey current and this may be due to the presence of soluble salts and ionic species which act as conducting medium. Conductivity of the samples ranged between $679 \mu \mathrm{S} / \mathrm{cm}$ to $2856 \mu \mathrm{S} / \mathrm{cm}$ (Fig.3) with an average value 1430 (Table5).The most desirable limit of EC in drinking water is prescribed as $1,500 \mu \mathrm{S} / \mathrm{cm}$. Electrical conductivity in pre monsoon seasons exceeds the permissible limit most of the sample in pre monsoon.

\subsection{Total Dissolved Solids:}

Many dissolved substance are undesirable in water. Dissolved minerals, gases and organic constituents may produce aesthetically displeasing colour, taste and odour (Subramanian, et, a, ). The TDS of ground water sample number S5 is high in the Udayarpalyam region, (Table-5). The concentration of total dissolved solids ranges varies from $876 \mathrm{mg} / 1$ to $1245 \mathrm{mg} / \mathrm{l}$ with an average value $1036 \mathrm{mg} / \mathrm{l}$ in the pre-monsoon (Fig.3). If the TDS of drinking water is more than $2000 \mathrm{mg} / \mathrm{l}$, would result to affect gastro intestinal irritation for human beings.

Table-1. Classification of groundwater based on TDS

\begin{tabular}{|l|l|c|}
\hline TDS (mg/l) & \multicolumn{1}{|c|}{ Water type } & No. of samples \\
\hline$<500$ & Desirable for drinking & - \\
\hline $500-1,000$ & Permissible for drinking & 14 \\
\hline$<3,000$ & Useful for irrigation & 11 \\
\hline$>3,000$ & Unfit for drinking and irrigation & - \\
\hline
\end{tabular}




\subsection{Total hardness:}

Based on the total hardness all the water samples are found within the permissible limit (500 $\mathrm{mg} / \mathrm{l})$ in pre monsoon season. The value of total hardness is observed from 155 to $389 \mathrm{mg} / \mathrm{l}$ in the pre-monsoon with an average value $260 \mathrm{mg} / \mathrm{l}$ (Fig.3).

\subsection{Cations:}

\subsubsection{Sodium:}

Sodium plays an important role in human body. Regulatory action is exercised by sodium, potassium, calcium and magnesium. The flux of these ions through cell membranes and other boundary layers sends signals that turn metabolic reactions on and off. The maximum permissible limit of sodium in water is $230 \mathrm{mg} / \mathrm{L}$. From table 2 it is seen that the concentration ranges of sodium for sample vary from 145 to $365 \mathrm{mg} / \mathrm{l}$ (Fig.4) with an average value $241 \mathrm{mg} / 1$ in pre monsoon season, except S2, S8, S11, S14, S17 and S24 all the other stations are all below the permissible limit and are suitable for drinking. Sodium is found in association with high concentration of chloride resulting in salinity (Jain, 2009).

\subsubsection{Potassium:}

Potassium has properties similar to sodium. In this study, the minimum and maximum recorded values of potassium were 12 to $54 \mathrm{mg} / \mathrm{l}$ (Fig.4) in the pre-monsoon with an average value $29 \mathrm{mg} / \mathrm{l}$. High concentration of potassium is due to the effect of fertilizers and other industrial activities located near the site.

\subsubsection{Calcium:}

The Calcium ionic concentration is varying from $53 \mathrm{mg} / 1$ to $195 \mathrm{mg} / 1$ (Fig.4) with an average of 92 $\mathrm{mg} / \mathrm{l}$ in the pre-monsoon periods. Calcium is the fifth element which is commonly present in all water bodies where it usually comes from the leaching of rocks. Calcium is very essential for nervous system and for formation of bones and teeth (Kannan and Sabu Joseph, 2009). The concentration of calcium in potable water ranges from 75 to $200 \mathrm{mg} / \mathrm{L}$. All the values of study area are within the permissible limit.

\subsubsection{Magnesium:}

Magnesium ion concentration in the Groundwater samples is mainly due to the leaching of magnesium bearing minerals. Based on the magnesium all the water samples are found within the permissible limit of WHO $(150 \mathrm{mg} / \mathrm{l})$. The maximum and minimum values recorded 17 to $57 \mathrm{mg} / 1$ (Fig.4) with an average value of $40 \mathrm{mg} / 1$ in pre monsoon season.

\subsection{Anions:}

\subsubsection{Chloride:}

Chloride ion concentration in the ground water is varying from $46 \mathrm{mg} / 1$ to $647 \mathrm{mg} / \mathrm{l}$ (Fig.5) with an average $221 \mathrm{mg} / \mathrm{l}$ in the pre monsoon. Chlorides are one of the major inorganic anions present in natural water. Chloride may be accumulated from agricultural activities, domestic sewage, and chloride-rich minerals or rocks. High concentration of chloride is considered to be the indicator of pollution by high organic wastes of animal or industrial origin (Gnanachandrasamy, et, $a l$,).

\subsubsection{Alkalinity:}

Alkalinity in water is due to the presence of carbonates, bicarbonates and hydroxides. Bicarbonates are the major contributes since they are included from the basic materials in the soil. Alkalinity is also a measure of water to absorb $\mathrm{H}^{+}$ions. Total alkalinity of the samples was found to range from $190 \mathrm{mg} / 1$ to $477 \mathrm{mg} / \mathrm{l}$ (Fig.5) with an average value $309 \mathrm{mg} / \mathrm{l}$. Alkalinity of water is capacity to neutralize acidic nature and is characterized by the presence of hydroxyl ions. Alkalinity around $150 \mathrm{mg} / \mathrm{l}$ has been found conductive to higher productivity of water bodies.

\subsubsection{Sulphate:}

Sulphate occurs naturally in all kinds of water. Drainage wastes are the main source of high sulphate concentration. Excess sodium and magnesium sulphate may cause cathartic action. A part from the natural rock sources. The samples had sulphate levels ranging between $13 \mathrm{mg} / 1$ to 165 
$\mathrm{mg} / \mathrm{l}$ (Fig.5) with an average value of $90 \mathrm{mg} / \mathrm{l}$ in pre monsoon season. The entire collected samples had lying within BIS limit, (Table-5).

\subsubsection{Fluoride:}

Fluoride is one of the main pollutants in groundwater, which generally occurs as a natural constituent. Bedrock containing fluoride minerals are generally responsible for high concentration of this ion in groundwater. The concentration of fluoride in groundwater varies from 1.26 to 0.11 $\mathrm{mg} / \mathrm{l}$ (Fig.5) with an average value of $0.68 \mathrm{mg} / \mathrm{l}$. The groundwater samples in the study area are found within the permissible limit of WHO $(1.5 \mathrm{mg} / \mathrm{l})$.

\subsubsection{Nitrate:}

The concentration of nitrate ranges from 12 to $36 \mathrm{mg} / 1$ with an average value of $23.2 \mathrm{mg} / 1$ (Fig.5), respectively. These nitrate concentration of the study area is within the permissible limit in all the sample locations.

\subsubsection{Phosphate:}

Generally phosphate occurs in natural water as inorganic (or) organic phosphates. Domestic sewage, agricultural effluents and detergents are the main source of phosphate in water. Excess phosphate may lead to growth of unwanted algae and eutrophication (Selvakumar, et, al,). The sample had phosphate content ranging from 0.6 to $0.04 \mathrm{mg} / \mathrm{l}$ (Fig.5), with an average value of 0.3 $\mathrm{mg} / \mathrm{l}$ in pre monsoon season (Table- 5)

\subsection{Dissolved Oxygen:}

The necessary limit of DO is $5 \mathrm{mg} / \mathrm{l}$. The table 2 indicates DO values which were ranged from 1.23 to $5.34 \mathrm{mg} / \mathrm{l}$ (Fig.6), with an average value of $2.72 \mathrm{mg} / \mathrm{l}$ in pre monsoon season (Table- 5). DO values are most important limiting factor of aquatic organisms. A measurement of DO is important in aquatic life ecology and it depends on temperature, pressure and salinity of water.

\subsubsection{Biological Oxygen Demand:}

The permissible limit of BOD is $4 \mathrm{mg} / \mathrm{l}$. The table 2 indicates BOD values which were ranged from 0.5 to $4.2 \mathrm{mg} / 1$ (Fig.6), with an average value of $1.8 \mathrm{mg} / 1$ in pre monsoon season (Table5).The BOD in general gives a qualitative index of organic substance which is degraded quickly in a short period.

\subsubsection{Chemical Oxygen Demand:}

The permissible limit of COD is $10 \mathrm{mg} / \mathrm{l}$. The table 1 indicates the values of COD in ground water were varied from 7.4 to $33.1 \mathrm{mg} / 1$ (Fig.6), with an average value of $17.2 \mathrm{mg} / \mathrm{l}$ in pre monsoon season (Table- 5), large quantities of domestic sewage and other wastes may contribute to the high value of $\mathrm{COD}$. 
Table-2. Sampling points of Udayarpalyam region

\begin{tabular}{|c|c|}
\hline Sampling Place & Sampling point.No \\
\hline Vallam & S1 \\
\hline Vettiyar Vettu & S2 \\
\hline Kattagaram & S3 \\
\hline Anaikudam & S4 \\
\hline Solankurichi & S5 \\
\hline Naduvalur & S6 \\
\hline Idaikurichi & S7 \\
\hline Koovathur & S8 \\
\hline Ulliyakudi & S9 \\
\hline Kattathur & S10 \\
\hline Kodankudi & S11 \\
\hline Managethi & S12 \\
\hline Karaikurichi & S13 \\
\hline Thevanur & S14 \\
\hline Thaluthalaimedu & S15 \\
\hline Devamangalam & S16 \\
\hline Suthamalli & S17 \\
\hline Suriyamanal & S18 \\
\hline Utkottai & S19 \\
\hline Periyakrishnapuram & S20 \\
\hline Kallathur & S21 \\
\hline Thathanoor & S22 \\
\hline Variyankaval & S23 \\
\hline Marudur & S24 \\
\hline Eravangudi & S25 \\
\hline
\end{tabular}

Table-3.Water quality Standard

\begin{tabular}{|c|c|c|c|}
\hline Parameters & WHO & ISI & BIS \\
\hline $\mathrm{pH}$ & $6.5-8.5$ & $6.5-9.2$ & $6.5-8.5$ \\
\hline $\mathrm{EC} \mu \mathrm{S} / \mathrm{cm}$ & 1500 & - & - \\
\hline TDS mg/l & 1000 & 1500 & 2000 \\
\hline $\mathrm{Ca} \mathrm{mg/1}$ & 200 & 200 & 200 \\
\hline $\mathrm{Mg} \mathrm{mg/1}$ & 150 & 100 & 100 \\
\hline $\mathrm{TH} \mathrm{mg} / \mathrm{l}$ & 500 & 600 & 600 \\
\hline $\mathrm{Na} \mathrm{mg} / \mathrm{l}$ & 200 & - & 150 \\
\hline $\mathrm{K}$ mg/l & 12 & - & - \\
\hline $\mathrm{HCO}_{3} \mathrm{mg} / \mathrm{l}$ & 500 & - & 400 \\
\hline $\mathrm{Cl}^{-} \mathrm{mg} / \mathrm{l}$ & 600 & 1000 & 1000 \\
\hline $\mathrm{SO}_{4}{ }^{2-} \mathrm{mg} / \mathrm{l}$ & 250 & 400 & 400 \\
\hline $\mathrm{NO}_{3}{ }^{-} \mathrm{mg} / \mathrm{l}$ & 45 & 45 & 45 \\
\hline $\mathrm{F}^{-} \mathrm{mg} / \mathrm{l}$ & 1.5 & 1.5 & 1.5 \\
\hline $\mathrm{PO}_{4}{ }^{2-} \mathrm{mg} / \mathrm{l}$ & 1 & 1 & 1 \\
\hline Temperature $^{0} \mathrm{C}$ & 30 & 30 & $25-30$ \\
\hline Turbidity NTU & $5 \mathrm{NTU}$ & $2 \mathrm{NTU}$ & $10 \mathrm{NTU}$ \\
\hline DO mg/l & 5.0 & 5 & 5 \\
\hline BOD mg/l & 5 & 5 & 4 \\
\hline COD mg/l & 10 & 10 & 10 \\
\hline
\end{tabular}

WHO World Health Organization, ISI Indian Standard Institution, BIS Bureau Indian Standards 
Table - 4. Methods used for estimation of various physico-chemical parameters

\begin{tabular}{|c|c|c|}
\hline S.No & Quality parameters studied & Method used \\
\hline 1. & $\mathrm{pH}$ & Recorded by $\mathrm{pH}$ meter \\
\hline 2. & Temperature & Thermometer \\
\hline 3. & Turbidity & Nephelometric method \\
\hline 4. & Electrical Conductivity & Measured by Conductivity meter \\
\hline 5. & Total Dissolved Solids & Evaporation method \\
\hline 6. & Total Hardness & EDTA Titrimetric method \\
\hline 7. & Calcium & EDTA Titrimetric method \\
\hline 8. & Magnesium & EDTA Titrimetric method \\
\hline 9. & Sodium & Flame photometric method \\
\hline 10. & Potassium & Flame photometric method \\
\hline 11. & Total Alkalinity & Indicator method \\
\hline 12. & Chloride & Gravimetric method \\
\hline 13. & Sulphate & Ion- selective electrode method \\
\hline 14. & Fluoride & Chromotropic acid method \\
\hline 15. & Nitrate & Spectrometric method \\
\hline 16 & Phosphate & Modified Winkler's method \\
\hline 17. & Dissolved Oxygen & Modified Winkler's method \\
\hline 18. & Biological Oxygen Demand & Titrated with an excess of $\mathrm{K}_{2} \mathrm{Cr} \mathrm{O}_{7}$ \\
\hline 19. & Chemical Oxygen Demand &
\end{tabular}

Table - 5. Physico-chemical characteristics of the groundwater of Udayarpalyam Taluk, Ariyalur District

\begin{tabular}{|c|c|c|c|c|c|c|c|c|c|c|c|c|c|c|c|c|c|c|c|}
\hline Station & $\mathrm{pH}$ & Temp & Turbidity & EC & TDS & TH & $\mathrm{Ca}$ & $\mathrm{Mg}$ & $\mathrm{Na}$ & $\mathbf{K}$ & $\mathrm{Cl}^{-}$ & TA & $\mathrm{SO}_{4}{ }^{2 \cdot}$ & $\mathrm{F}^{*}$ & $\mathrm{NO}_{3}{ }^{\circ}$ & $\mathrm{PO}_{4}{ }^{2 *}$ & DO & BOD & COD \\
\hline S1 & 7.12 & 28.5 & 1.21 & 857 & 1234 & 245 & 78 & 40 & 221 & 26 & 224 & 345 & 145 & 0.82 & 19 & 0.12 & 2.54 & 1.2 & 14.2 \\
\hline $\mathrm{S} 2$ & 8.22 & 27.1 & 0.12 & 2789 & 998 & 324 & 117 & 51 & 365 & 21 & 423 & 477 & 78 & 0.74 & 26 & 0.34 & 2.43 & 4.2 & 7.6 \\
\hline S3 & 7.56 & 32.3 & 1.13 & 1805 & 987 & 290 & 54 & 57 & 165 & 16 & 73 & 234 & 123 & 1.23 & 18 & 0.22 & 1.53 & 1.3 & 13.1 \\
\hline S4 & 8.13 & 26.4 & 0.54 & 1120 & 1122 & 265 & 86 & 43 & 145 & 31 & 133 & 467 & 92 & 0.78 & 23 & 0.25 & 2.21 & 1.3 & 18.1 \\
\hline S5 & 7.3 & 27.3 & 2.32 & 1230 & 1245 & 320 & 135 & 45 & 187 & 37 & 266 & 367 & 112 & 0.23 & 23.1 & 0.09 & 4.12 & 0.9 & 33.1 \\
\hline S6 & 7.54 & 27.4 & 1.13 & 1256 & 989 & 324 & 94 & 56 & 208 & 49 & 143 & 243 & 64 & 0.32 & 14 & 0.19 & 2.11 & 1.3 & 26.3 \\
\hline S7 & 7.87 & 28.6 & 1.13 & 1400 & 1193 & 232 & 75 & 38 & 178 & 15 & 177 & 440 & 156 & 0.45 & 27 & 0.55 & 1.65 & 1.2 & 10.3 \\
\hline S8 & 7.5 & 31.9 & 0.45 & 2245 & 876 & 255 & 105 & 37 & 355 & 24 & 345 & 432 & 68 & 0.67 & 31.4 & 0.33 & 2.54 & 1.4 & 15.4 \\
\hline S9 & 7.23 & 26.1 & 1.45 & 1345 & 938 & 178 & 88 & 21 & 265 & 54 & 57 & 255 & 23 & 0.18 & 12 & 0.26 & 1.23 & 1.8 & 20.1 \\
\hline $\mathrm{S} 10$ & 8.52 & 30.2 & 2.32 & 956 & 890 & 165 & 64 & 25 & 178 & 15 & 144 & 276 & 122 & 0.4 & 17.2 & 0.42 & 2.22 & 4.2 & 9.5 \\
\hline \$11 & 7.67 & 31.2 & 1.11 & 679 & 1154 & 255 & 86 & 41 & 322 & 32 & 155 & 223 & 37 & 1.23 & 36 & 0.13 & 1.64 & 0.5 & 30.1 \\
\hline $\mathrm{S} 12$ & 8.21 & 26.1 & 1.14 & 1469 & 890 & 202 & 58 & 35 & 234 & 43 & 245 & 215 & 57 & 0.45 & 21 & 0.11 & 3.11 & 2.2 & 19.2 \\
\hline $\mathrm{S} 13$ & 7.73 & 26.4 & 0.67 & 876 & 955 & 212 & 97 & 28 & 212 & 36 & 288 & 321 & 165 & 1.03 & 24.5 & 0.31 & 2.67 & 3.5 & 9.23 \\
\hline S14 & 7.94 & 30.5 & 2.43 & 1775 & 895 & 173 & 82 & 22 & 344 & 32 & 87 & 221 & 114 & 1.06 & 14.8 & 0.08 & 2.25 & 1.2 & 17.1 \\
\hline S15 & 8.22 & 28.4 & 1.15 & 1554 & 1112 & 389 & 72 & 50 & 225 & 29 & 178 & 216 & 97 & 1.26 & 34 & 0.04 & 5.34 & 1.3 & 32.1 \\
\hline S16 & 8.32 & 31.6 & 1.43 & 1255 & 1143 & 237 & 103 & 32 & 276 & 26 & 137 & 366 & 122 & 0.17 & 16.3 & 0.39 & 1.56 & 1.1 & 15.1 \\
\hline \$17 & 7.52 & 30.1 & 0.21 & 976 & 978 & 155 & 83 & 17 & 345 & 53 & 95 & 198 & 34 & 0.98 & 32 & 0.45 & 3.56 & 2.4 & 11.2 \\
\hline $\mathrm{S} 18$ & 7.95 & 29.8 & 0.89 & 2856 & 1154 & 267 & 112 & 37 & 223 & 32 & 647 & 421 & 89 & 1.25 & 25 & 0.3 & 2.12 & 1.3 & 13.5 \\
\hline$\$ 19$ & 8.11 & 27.5 & 0.11 & 1445 & 879 & 189 & 73 & 28 & 165 & 18 & 185 & 243 & 134 & 0.14 & 27.4 & 0.21 & 3.23 & 2.3 & 24.3 \\
\hline S20 & 7.91 & 31.6 & 1.15 & 1765 & 1211 & 313 & 96 & 52 & 145 & 12 & 278 & 305 & 98 & 1.08 & 17 & 0.31 & 2.43 & 1.1 & 16.1 \\
\hline \$21 & 7.12 & 28.7 & 1.76 & 998 & 949 & 302 & 65 & 57 & 246 & 16 & 46 & 231 & 55 & 0.11 & 34 & 0.28 & 1.34 & 2.3 & 25.2 \\
\hline S22 & 8.21 & 32.6 & 0.76 & 870 & 1089 & 355 & 195 & 39 & 231 & 36 & 423 & 374 & 105 & 0.22 & 22.6 & 0.16 & 4.11 & 2.1 & 8.4 \\
\hline S23 & 7.63 & 29.9 & 2.54 & 1245 & 879 & 265 & 66 & 48 & 213 & 14 & 267 & 246 & 13 & 0.53 & 18.6 & 0.47 & 2.54 & 2.4 & 7.4 \\
\hline \$24 & 7.65 & 31.8 & 1.54 & 978 & 978 & 323 & 96 & 55 & 315 & 27 & 88 & 264 & 69 & 0.64 & 15.8 & 0.45 & 5.23 & 1.2 & 11.3 \\
\hline S25 & 8.24 & 27.6 & 1.13 & 1333 & 1123 & 234 & 53 & 44 & 232 & 33 & 170 & 285 & 85 & 1.12 & 28 & 0.28 & 3.14 & 1.3 & 15.4 \\
\hline Maxi & 8.52 & 32.6 & 2.54 & 2856 & 1245 & 389 & 195 & 57 & 365 & 54 & 647 & 477 & 165 & 1.26 & 36 & 0.6 & 5.34 & 4.2 & 33.1 \\
\hline Mini & 7.12 & 26.1 & 0.11 & 679 & 876 & 155 & 53 & 17 & 145 & 12 & 46 & 198 & 13 & 0.11 & 12 & 0.04 & 1.23 & 0.5 & 7.4 \\
\hline Average & 7.82 & 29.2 & 1.19 & 1430 & 1036 & 259.7 & 92 & 40 & 241 & 29 & 221 & 308.9 & 90.2 & 0.68 & 23.2 & 0.3 & 2.719 & 1.84 & 17.2 \\
\hline
\end{tabular}


All the values are expressed in $\mathrm{mg} / \mathrm{l}$ except $\mathrm{EC}$ measured in $\mu \mathrm{S} / \mathrm{cm}$ and $\mathrm{pH}$ is unit less

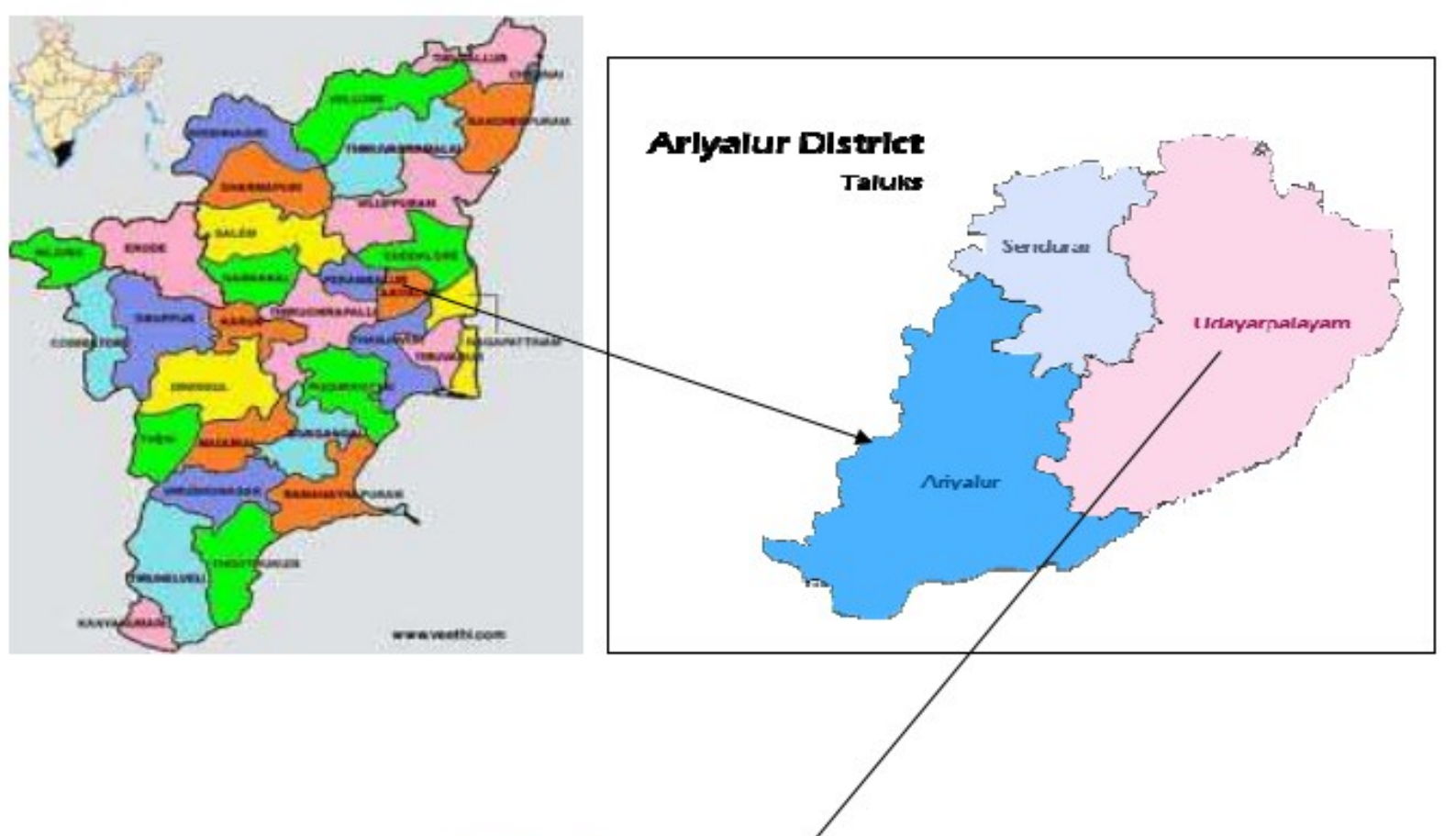

Ariyalur : Udayarpalayam Taluk

Revenue Villages

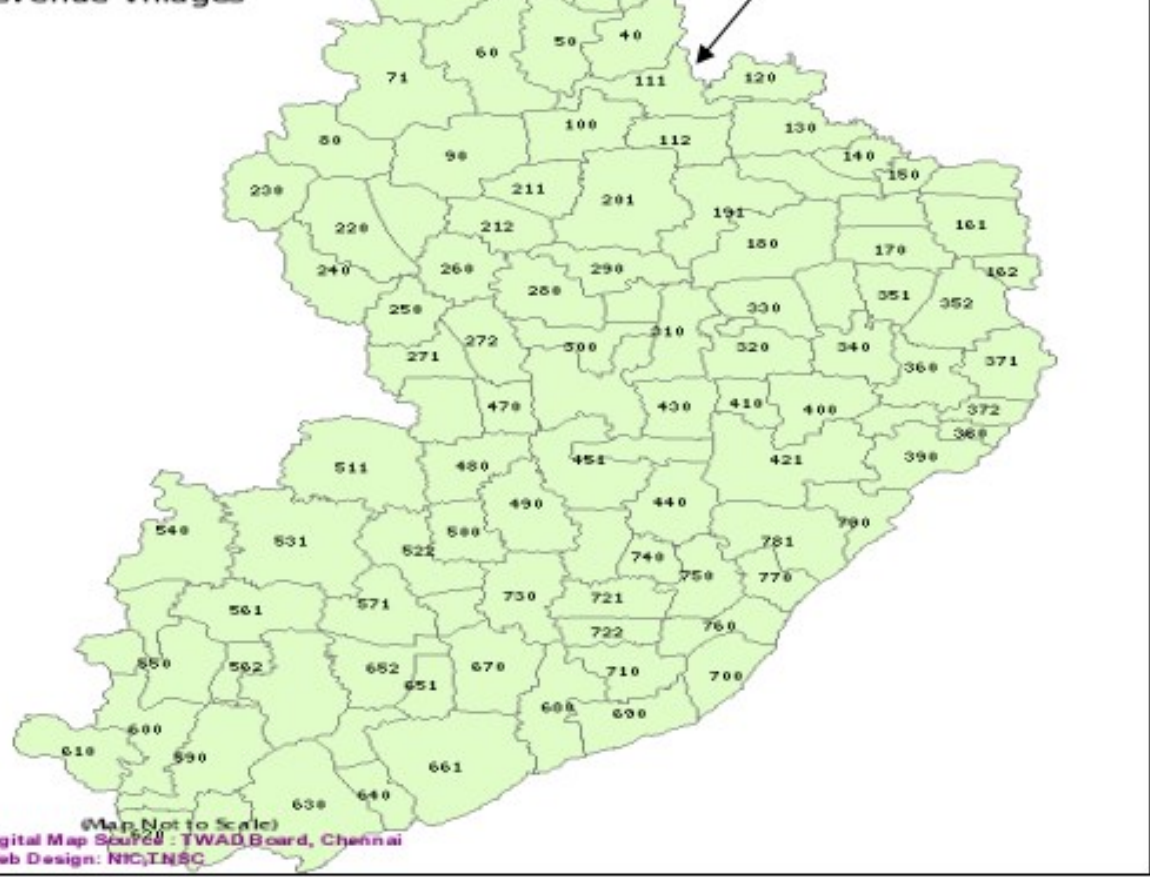

Fig. 1 Location map of the study area 


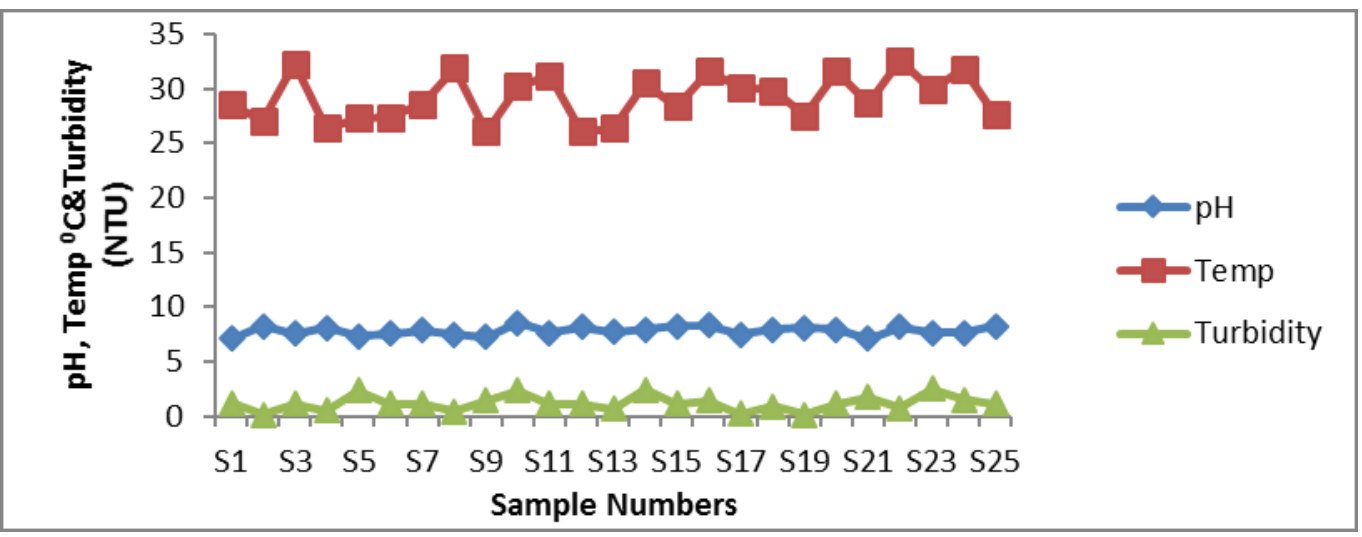

Fig - 2. pH, Temperature and Turbidity variation of the study area

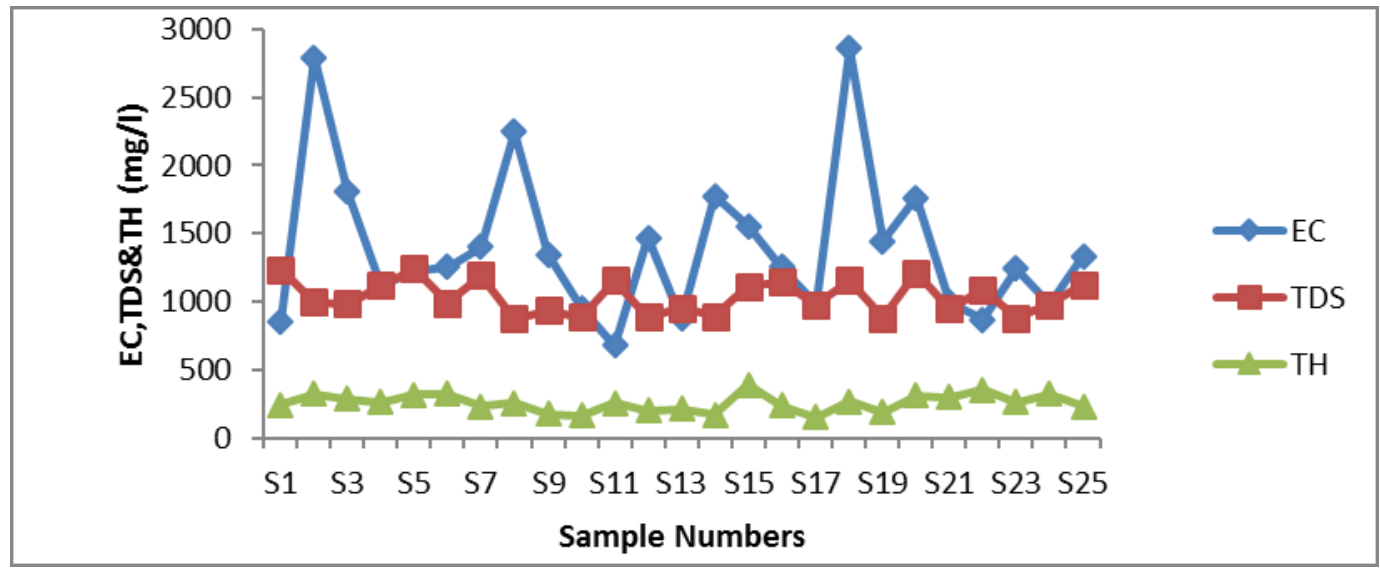

Fig - 3. EC, TDS and TH variation of the study area

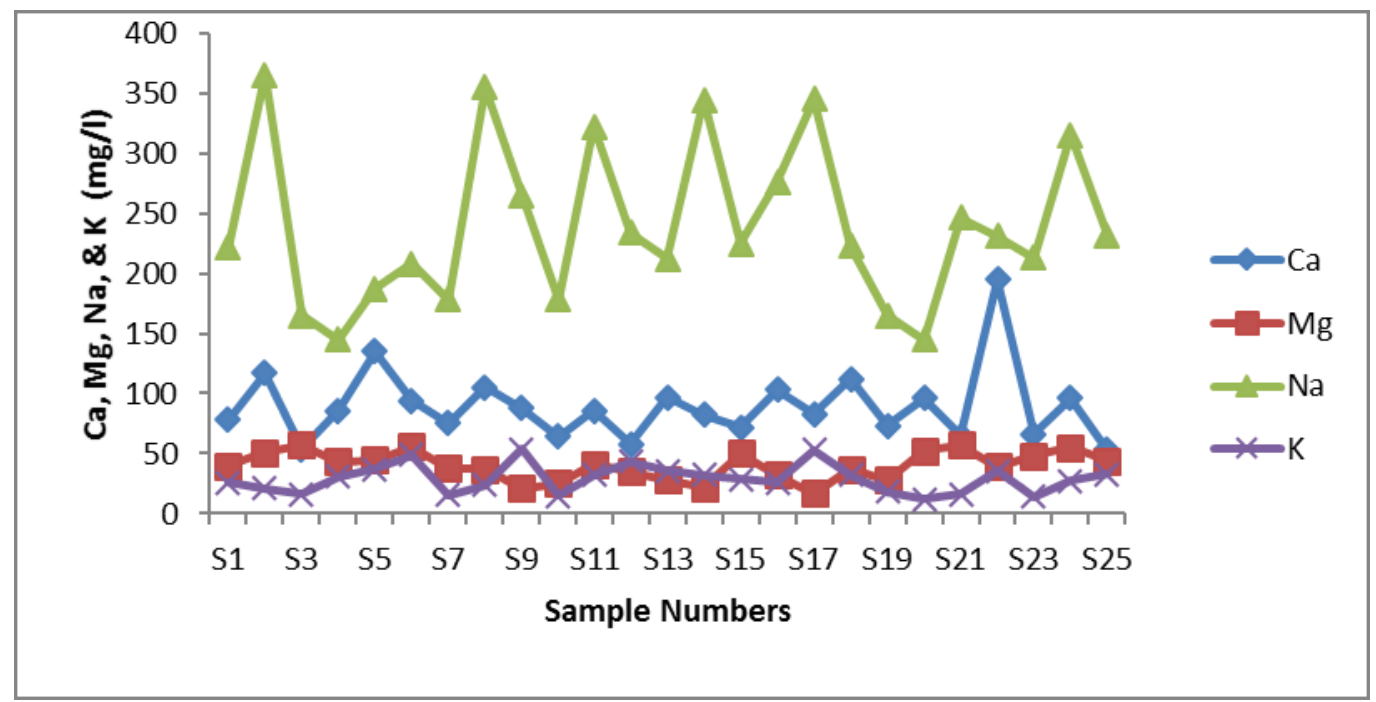

Fig - 4. Cation variation of the study area 


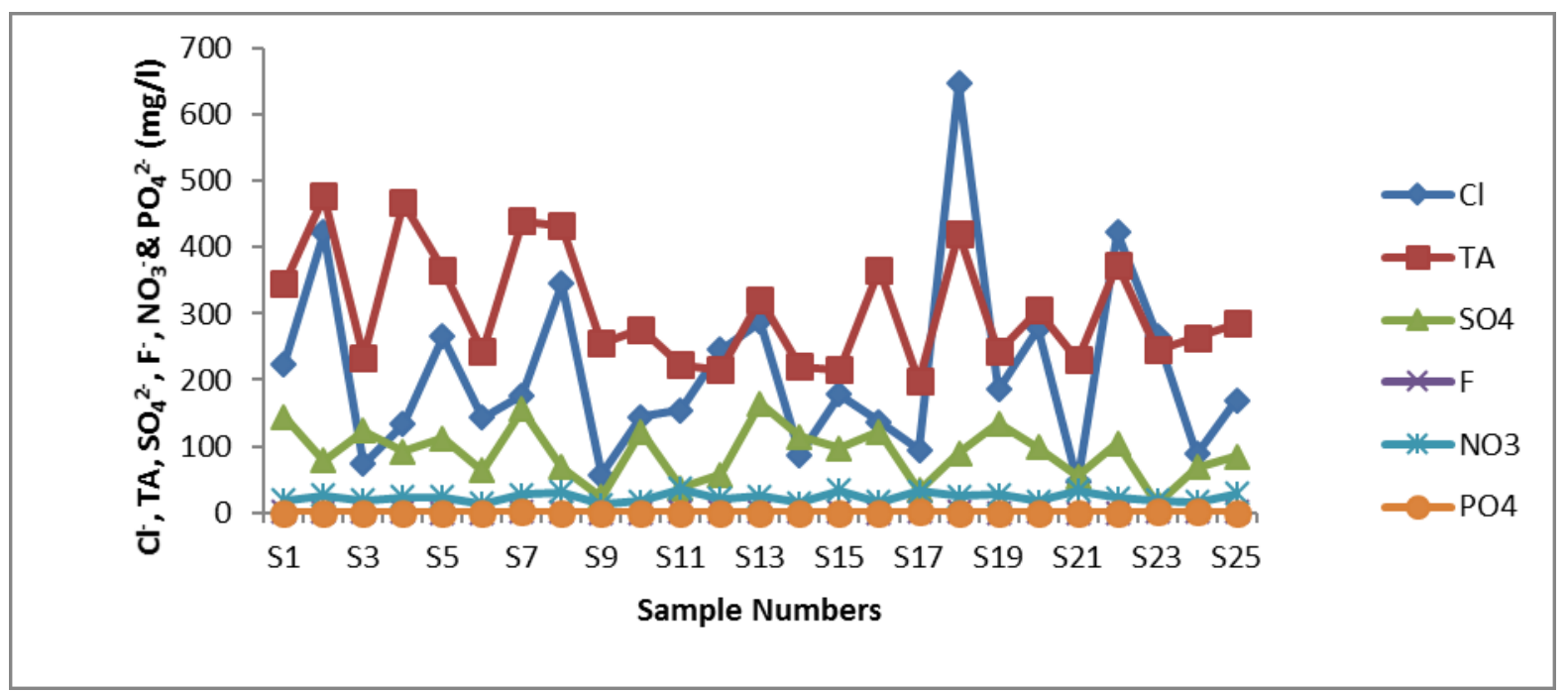

Fig - 5. Anion variation of the study area

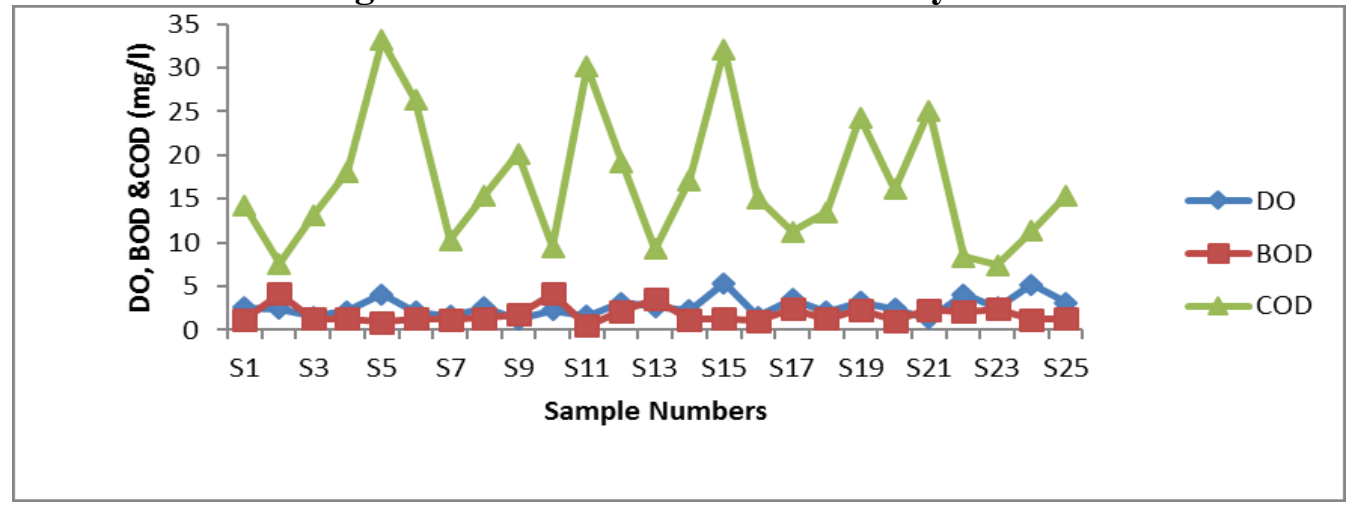

Fig - 6. DO, BOD and COD variation of the study area

\section{CONCLUSION}

Water is one of the abundantly available substances in nature and also called an elixir of life. The study assessed the evolution of water quality in groundwater and open well water of Udayarpalyam Taluk, Ariyalur district. The assessment of groundwater for drinking has been evaluated by the standard guidelines. High concentration of EC, TDS, $\mathrm{Na}, \mathrm{K}, \mathrm{TA}, \mathrm{Ca}, \mathrm{Mg}$ and $\mathrm{Cl}^{-}$at a number of areas clearly indicates the unsuitability of groundwater for drinking purpose. Groundwater samples are slightly alkaline nature. Similarly, Turbidity, $\mathrm{F}^{-}, \mathrm{NO}_{3}{ }^{-}, \mathrm{PO}_{4}{ }^{2-}, \mathrm{DO}, \mathrm{BOD}$ and COD concentration in the water samples are all within the permissible limit of drinking water. Most of the groundwater sample numbers S2, S8 ,S15, S18, S20, S23 and S25 is not suitable for drinking purpose, because in the presence of excess EC, TDS, $\mathrm{TH}, \mathrm{Ca}, \mathrm{Mg}, \mathrm{K}$ and $\mathrm{Cl}^{-}$. This information must be shared with people of the area and suggested to improve the water quality. The data may also be shared with the public health.

\section{References}

[1] S. Selvakumar. K. Ramkumar . N. Chandrasekar. N. S. Magesh and S. Kaliraj. Groundwater quality and its suitability for drinking and irrigational use in the Southern Tiruchirappalli district, Tamil Nadu, India. Applied water science. (2014), DOI 10.1007/s13201-014-0256-9.

[2] P. Subramanian. R. Prabhakaran K. Babu. S. Chidambaram . R. Senthilkumar and K. Srinivasamoorthy. Evolution of groundwater quality in Andimadam area, Perambalur District, Tamilnadu, India. International Journal of Current Research. (2012), Vol. 4, PP: 168-172.

[3] P. J. Sajil Kumar and E. J. James. Physicochemical parameters and their sources in groundwater in the Thirupathur region, Tamil Nadu, South India. Appl Water Sci. (2013), Vol. 3, PP: 219-228. 
[4] APHA. Standard methods for the examination of water and waste water.(2005), $21^{\text {st }}$ Edn. American Public Health Association, Washington, DC

[5] N. Mani and D. Kannan. Assessment of ground water quality in various parts of Thanjavur District, Tamilnadu (India). International Letters of Chemistry, Physics and Astronomy. (2015), Vol.3, PP: 90-99.

[6] S.M. Deshpande and K. R. Aher. Evaluation of Groundwater Quality and its Suitability for Drinking and Agriculture use in Parts of Vaijapur, District Aurangabad, MS, India. Research Journal of Chemical Sciences. (2012), Vol. 2(1), PP: 25-31.

[7] K. L. Prakash and R. K. Somashekar. Groundwater quality - Assessment on Anekal Taluk , Bangalore Urban district, India. Journal of Environmental Biology. (2006), Vol. 27(4), PP: 633637.

[8] WHO (2004) Guidelines for drinking-water quality, Vol 1, Recommendations, $3^{\text {rd }}$ Edn. World Health Organisation, Geneva, p 515

[9] R. Nandababu Singh Laishram. Physico- chemical study of ground water quality of some areas of Imphal city, Manipur- $2^{\text {nd }}$ Phase. Journal of Chemical and Pharmaceutical Research. (2013), Vol. 5(8), PP: 110-114.

[10] P. Florence Lilly. A. Paulraj and T. Ramachandramoorthy. Assessment of Ground Water Quality of Salem Taluk in Salem District, Tamil Nadu,India. International Journal of Research in Chemistry and Environment. (2012), Vol. 2, PP: 323-337.

[11] P.N.Patil . D.V.Sawant and R.N. Deshmukh . Physicochemical parameters for testing of waterA. review. Int. Journal of Environmental Sciences. (2012), Vol. 3(3), pp: 1194-1207.

[12] G. Gnanachandrasamy.T. Ramkumar. S. Venkatramanan. S. Vasudevan . S. Y. Chung and M. Bagyaraj. Accessing groundwater quality in lower part of Nagapattinam district, Southern India: using hydro geochemistry and GIS interpolation techniques Appl Water Sci (2015), Vol. 5, PP: 3955.

[13] D.Navneet Kumar and K. Sinha. Drinking water quality management through correlation studies among various physicochemical parameters: A case study. International Journal of Environmental Sciences. (2010), Vol. 1, PP: 253-259

[14] BIS. Drinking water specification. Bureau of Indian Standards. (2000), New Delhi IS 10500.

[15] S.C. Gupta. Chemical character of ground waters in Nagpur district, Rajasthan. Indian J. Environ. Hlth. (1991), 33(3), PP: 341- 49.

[16] N. Kannan and P. Sabu Joseph. Quality of groundwater in the shallow aquifers of a Paddy dominated agricultural river basin, Kerala, India. World Academy of Science, Engineering and Technology. (2009), Vol. 52, PP: 475-482.

[17] R. Nagarajan. N. Rajmohan.U. Mahendran and S. Senthamilkumar. Evaluation of groundwater quality and its suitability for drinking and agriculture use in Thanjavur District, Tamil Nadu, India. Environ. Monit. Assess. (2010), 171, PP: 289-308.

[18] C.K.Jain . Assessment of ground water quality for drinking purpose, Nainital, Uttarakhand, India, Environ Monit Assess, Springer. (2009), Vol. 166, PP: 663-673. 